\title{
IMPLEMENTASI MODEL PEMBELAJARAN KOOPERATIF TIPE STUDENT TEAM ARCHIEVEMEN DIVISION (STAD) UNTUK MENINGKATKAN MOTIVASI DAN HASIL BELAJAR TATA HIDANG
}

\author{
Ni Luh Astrini Laksemiwati \\ SMK Negeri 2 Singaraja \\ Email: astrinilaksemi@gmail.com
}

\begin{abstract}
ABSTRAK
Tujuan dari diadakannya penelitian ini adalah untuk meningkatkan motivasi belajar dan hasil belajar tata hidang siswa kelas XI A3 SMK Negeri 2 Singaraja Tahun Pelajaran 2016/2017 melalui implementasi model pembelajaran kooperatif tipe Student Team Achievemen Division. Penelitian ini adalah penelitian tindakan kelas (PTK). Subjek yang dipilih dalam penelitian ini adalah siswa kelas XI A3 SMK Negeri 2 Singaraja tahun pelajaran 2016/2017 yang berjumlah 38 orang. Sedangkan objek penelitian tindakan kelas ini adalah motivasi dan hasil belajar siswa pada mata pelajaran tata hidang. Data motivasi belajar siswa dikumpulkan dengan angket/kuesioner, sedangkan data hasil belajar siswa dikumpulkan dengan tes. Analisis data yang digunakan pada penelitian ini menggunakan analisis data deskriptif. Berdasarkan analisis data yang dilakukan dapat disimpulkan bahwa implementasi model pembelajaran kooperatif tipe Student Team Achievemen Division (STAD) dapat meningkatkan motivasi dan hasil belajar Tata Hidang siswa kelas XI A3 SMK Negeri 2 Singaraja tahun pelajaran 2016/2017.
\end{abstract}

Kata kunci: model pembelajaran STAD, motivasi belajar, hasil belajar siswa

\begin{abstract}
The purpose of this research was to improve learning motivation and learning outcomes in the field of XI A3 management at SMK Negeri 2 Singaraja 2016/2017 Academic Year through the implementation of a cooperative learning model of the Student Team Achievement Division. This research is classroom action research. The subjects chosen in this study were students of class XI A3 of SMK Negeri 2 Singaraja in the 2016/2017 academic year, which amounted to 38 people. While the object of this class action research is the motivation and learning outcomes of students on subject matter subjects. Data on student learning motivation was collected by questionnaire / questionnaire, while data on student learning outcomes were collected by tests. Data analysis used in this study used descriptive data analysis. Based on the data analysis conducted it can be concluded that the implementation of the cooperative learning model Student Team Achievement Division (STAD) type can improve the motivation and learning outcomes of the HIS class XI A3 students of SMK Negeri 2 Singaraja 2016/2017 academic year.
\end{abstract}

Keywords: STAD learning model, learning motivation, student learning outcomes 


\section{PENDAHULUAN}

Upaya pemerintah untuk meningkatkan mutu pendidikan terus dilakukan, salah satunya adalah melalui penyempurnaan Kurikulum. Kurikulum yang dikembangkan dan dilaksanakan sebagai penyempurnaan kurikulum KTSP adalah kurikulum 2013. Tujuan kurikulum 2013 adalah untuk menyiapkan generasi muda Indonesia yang memiliki kompetensi sikap, pengetahuan dan keterampilan yang sangat baik.

\begin{tabular}{llrr}
\multicolumn{2}{c}{ Kegiatan } & pembelajaran pada \\
kurikulum 2013 diharapkan untuk \\
membentuk & watak, membangun
\end{tabular}
pengetahuan, sikap dan kebiasaan-kebiasaan untuk meningkatkan mutu kehidupan peserta didik. Kegiatan pembelajaran diharapkan mampu memberdayakan semua potensi peserta didik untuk menguasai kompetensi yang diharapkan. Pemberdayaan diarahkan untuk mendorong pencapaian kompetensi dan perilaku khusus supaya setiap individu mampu menjadi pembelajar sepanjang hayat dan mewujudkan masyarakat belajar.

Kegiatan pembelajaran perlu menggunakan prinsip yang: (1) berpusat pada peserta didik, (2) mengembangkan kreativitas peserta didik, (3) menciptakan kondisi menyenangkan dan menantang, (4) bermuatan nilai, etika, estetika, logika, dan kinestetika, dan (5) menyediakan pengalaman belajar yang beragam

Model pembelajaran yang dirasa sesuai dengan prinsip pembelajaran tersebut adalah model pembelajaran kooperatif tipe STAD (Student Team Achievemen Division). Pembelajaran kooperatif merupakan model pembelajaran dimana siswa belajar dalam kelompok-kelompok kecil yang memiliki tingkat kemampuan yang berbeda. Model pembelajaran kooperatif berbeda dengan sekedar belajar dalam kelompok, perbedaan ini terletak pada adanya unsur-unsur dasar dalam pembelajaran kooperatif yang tidak ditemui dalam pembelajaran kelompok yang dilakukan asal-asalan. Prosedur model pembelajaran koopertatif yang dilakukan dengan benar akan memungkinkan guru dapat mengelola kelas dengan lebih efektif dan efisien.
STAD (Student Team Achievemen Division) ini dikembangkan oleh Slavin (2010) yang merupakan salah satu tipe cooperative learning yang menekankan interakssi diantara siswa untuk saling memotivasi dan saling membantu dalam menguasai materi dan pencapaian prestasi secara maksimal, dan juga merupakan salah satu model pembelajaran kooperatif yang sederhana dan baik untuk guru yang baru mulai menggunakan model kooperatif dalam kelas, STAD juga merupakan suatu model pembelajaran kooperatif yang efektif. Gagasan utama STAD adalah untuk memotivasi siswa supaya dapat saling mendukung dan membantu satu sama lain dalam menguasi pengetahuan yang diajarkan oleh guru. Jika para siswa ingin agar timnya mendapatkan penghargaan tim, mereka harus membantu teman satu timnya untuk mempelajari materinya (Slavin: 2010).

Setelah mengetahui keunggulan model STAD (Student Team Achievemen Division) sangat cocok diterapkan di kelas XI A3 SMK Negeri 2 Singraja. Berdasarkan hasil observasi terhadap proses pembelajaran dan wawancara dengan siswa yang sekaligus dengan pemberian angket, terungkap beberapa permasalahan yang dapat diidentifikasi sebagai berikut :

Pertama, berdasarkan angket yang disebarkan kepada siswa serta dari hasil observasi dikelas XI A3 yang berjumlah 38 orang siswa menyatakan kurang menyiapkan diri untuk mengikuti pembelajaran di kelas walaupun mereka sudah mengetahui materi yang akan diajarkan oleh guru di kelas. Kedua, dalam proses pembelajaran motivasi siswa untuk belajar masih rendah dan cenderung pasif. Rendahnya motivasi siswa untuk belajar ditunjukkan dari kurangnya perhatian siswa dalam kegiatan pembelajaran, masih sedikit anak yang memberikan tanggapan ketika guru menyampaikan suatu pertanyaan mengenai materi yang dipelajari. Hal ini telah disadari oleh guru, sehingga guru mencoba meningkatkan motivasi siswa melalui metode demonstrasi, serta menggunakan media simulasi. Akan tetapi upaya ini belum 
mampu meningkatkan motivasi siswa, malahan siswa hanya terpaku melihat simulasi yang ditampilkan oleh guru, sehingga pembelajarannya menjadi kurang efektif.

Dengan menerapkan model pembelajaran kooperatif tipe STAD (Student Team Achievemen Division) diharapkan mampu mengatasi permasalahan tersebut. Siswa menjadi lebih termotivasi dan aktif dalam mengikuti pelajaran, sehingga nantinya berpengaruh terhadap hasil belajar siswa.

Berdasarkan uraian di atas dapat dikatakan bahwa tercapainya tujuan pembelajaran terutama untuk peningkatan hasil belajar dapat dipengaruhi oleh model pembelajaran yang diterapkan pada proses pembelajaran serta motivasi siswa dalam memperjelas tujuan belajar. Maka dalam penelitian ini, akan dikaji lebih dalam tentang Implementasi Model Pembelajaran Kooperatif Tipe Student Team Achievemen Division untuk Meningkatkan Motivasi dan Hasil Belajar Tata Hidang Siswa Kelas XI A3 SMK Negeri 2 Singaraja Tahun Pelajaran 2016/2017.

\section{METODE PENELITIAN}

Penelitian tindakan kelas ini dilaksanakan di SMK Negeri 2 Singaraja Lokasinya di Jalan Srikandi No. 9 Singaraja. Penelitian ini akan dilaksanakan dalam waktu 3 bulan yaitu dari bulan September 2017 sampai bulan November 2017.

Subjek yang dipilih dalam penelitian ini adalah siswa kelas XI A3 SMK Negeri 2 Singaraja tahun pelajaran 2016/2017 yang berjumlah 38 orang. Objek penelitian tindakan kelas ini adalah motivasi dan hasil belajar siswa pada mata pelajaran tata hidang

Berdasarkan observasi awal yang telah dilakukan, model pembelajaran yang akan digunakan adalah model pembelajaran STAS. STAD (Student Team Achievemen Division) merupakan satu sistem belajar kelompok dimana siswa di bentuk ke dalam kelompok yang terdiri dari 4-5orang secara heterogen. STAD mengacu kepada belajar kelompok yang menyajikan informasi akademik baru kepada siswa menggunakan presentasi verbal atau teks. Dalam hal ini model pembelajaran kooperatif tipe STAD adalah model yang paling sederhana untuk diterapkkan pada siswa. Jumlah anggota yang sedikit dalam setiap kelompok memudahkan siswa berkomunikasi dengan teman sekelompok.

Pentingnya pembagian kelompok seperti ini didasarkan pada pemikiran bahwa siswa lebih mudah menemukan dan memahami konsep yang sulit jika masalah itu dipelajari bersama. Model pembelajaran kooperatif tipe STAD diharapkan dapat lebih bermakna bagi siswa, melalui segala macam kegiatan yang dilakukan secara langsung oleh siswa di dalam kelompoknya masing-masing.

Penelitian ini dilaksanakan dalam 2 siklus pembelajaran. Penelitian tindakan kelas ini terdiri dari dua siklus. Dalam setiap siklus dibagi menjadi 4 tahap kegiatan yaitu, (1) perencanaan, (2) tindakan, (3) observasi/evaluasi, dan (4) refleksi. Adapun alur penelitiannya dapat disajikan seperti Gambar 1.

Pembagian materi pada tiap siklus didasarkan pada keterkaitan antara kompetensi dasar dan indikator pencapaian hasil belajar siswa.

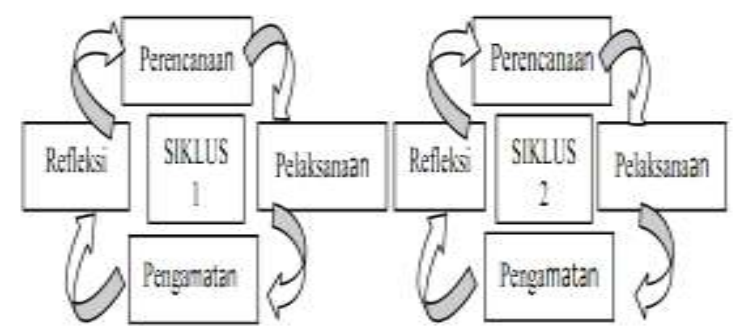

Gambar 1. Siklus PTK

Untuk mengukur motivasi belajar siswa pada mata pelajaran tata hidang menggunakan lembar angket/kuesioner motivasi belajar siswa yang telah dipersiapkan. Sedangkan untuk mengukur hasil belajar siswa menggunakan tes. Tes dilakukan kepada siswa beberapa menit sebelum jam pelajaran berakhir yaitu dengan diberikan post test. Data dari test ini untuk 
memperkuat data yang telah diperoleh berdasarkan lembar observasi.

Setelah data motivasi belajar dan hasil belajar siswa terkumpul, selanjutnya dilakukan analisis data dengan menggunakan analisis deskriptif.

\section{HASIL DAN PEMBAHASAN Hasil Penelitian}

Secara umum, pelaksanaan pembelajaran di dalam kelas selama penelitian telah berlangsung sesuai dengan rencana pelaksanaan pembelajaran yang telah disusun. Penelitian ini dilaksanakan dalam dua siklus, bertempat di SMK Negeri 2 Singaraja, Kabupaten Buleleng Tahun Pelajaran 2016/2017. Subjek dalam penelitian ini sebanyak 38 orang siswa. Pada awal kegiatan, peneliti yang bertindak sebagai guru menyampaikan kepada siswa bahwa kegiatan pembelajaran tata hidang untuk pokok bahasan napkin dan menu akan dilaksanakan melalui implementasi model pembelajaran model kooperatif tipe Student Team Achievemen Division.

Peneliti menggunakan waktu kurang lebih 15 menit pada pertemuan pertama untuk mensosialisasikan atau memberikan gambaran kepada siswa mengenai model pembelajaran yang diterapkan selama pembelajaran. Pada kesempatan ini guru menyampaikan bahwa dalam setiap pembelajaran siswa diberikan LKS maupun kuis diakhir pembelajaran pada setiap pertemuan dengan tujuan dapat meningkatkan pemahaman siswa.

Proses pembelajaran pada siklus I berlangsung dalam 3 kali pertemuan, yang terdiri atas 2 kali pertemuan untuk kegiatan belajar mengajar, 1 kali pertemuan untuk tes akhir siklus. Pada pertemuan pertama, peneliti mengecek kehadiran siswa dan seluruh siswa hadir. Peneliti menggunakan waktu kurang lebih 15 menit pada pertemuan pertama untuk mensosialisasikan atau memberikan gambaran kepada siswa mengenai model pembelajaran yang diterapkan selama proses pembelajaran. Peneliti menyampaikan indikator dan tujuan pembelajaran kepada siswa. Pada kegiatan inti dimulai dengan penyajian materi oleh peneliti. Kemudian siswa di minta bergabung ke dalam kelompok yang terdiri dari 4-5 orang. Kelompok yang dibentuk adalah kelompok yang heterogen yang terdiri atas siswa yang memiliki latar belakang berbeda baik dari segi prestasi, jenis kelamin dan suku.

Guru membagikan LKS kepada masing-masing kelompok dan meminta untuk mengerjakan lks itu bersama-sama. Guru meminta anggota kelompok harus bekerja sama. Setelah masing-masing kelompok selesai mengerjakan LKS yang diberikan oleh guru, maka guru meminta hasil masing-masing kelompok untuk dilakukan pemeriksaan hasil oleh kelompok yang lain. Kelompok yang tidak menjawab diminta untuk mendengarkan dan memberi tanggapan atas jawaban kelompok lainnya.

Setelah semua kelompok dapat menjawab dan memberi tanggapan maka tugas guru untuk melakukan konfirmasi dan penguatan atas kesalahan jawaban atau perbedaan pendapat yang mungkin terjadi pada saat diskusi. Di akhir pertemuan guru memberikan lembar kuesioner motivasi belajar, untuk mengetahui motivasi belajar siswa dalam mengikuti pembelajaran yang telah berlangsung.

Hasil belajar siswa pada siklus I diperoleh data sebagai berikut: sebanyak 26 orang siswa atau $68 \%$ dinyatakan tuntas, dan sisanya yaitu 12 orang siswa atau $32 \%$ telah dinyatakan belum tuntas memenuhi standar ketuntasan. Dengan demikian ketuntasan hasil belajar siswa pada siklus I baru mencapai $68 \%$ dan skor motivasi belajar siswa setelah penerapan model model kooperatif tipe Student Team Achievemen Division adalah sebesar 2032 dan rataratanya sebesar 53.5 yang berkatagori positif

Berdasarkan hasil analisis pada siklus I terungkap beberapa kendala dan hambatan yang dijadikan sebagai refleksi untuk siklus II terkait dengan proses pembelajaran model kooperatif tipe Student Team Achievemen Division yang diterapkan di kelas XI A3 SMK Negeri 2 Singaraja untuk pokok bahasan napkin dan menu, yaitu sebagai berikut.

1) Untuk motivasi belajar siswa sudah positif, hal ini terjadi karena siswa sudah mulai menyukai model 
pembelajaran kooperatif tipe Student Team Achievemen Division.

2) Namun proses pembelajaran pada siklus I secara umum belum dapat berjalan secara optimal. Hal ini disebabkan karena masih ada siswa yang masih terbiasa dengan pola pembelajaran sebelumnya yaitu siswa hanya duduk mendengarkan penjelasan dari peneliti atau belajar berkelompok tapi hasil diskusi kelompoknya tidak dibahas oleh kelompok yang lainnya.

3) Dalam diskusi kelompok maupun kelas, siswa kurang aktif dalam mengemukakan pendapat dan hanya mengandalkan pendapat teman yang pintar dari kelompoknya.

4) Siswa masih kurang aktif untuk mengajukan pendapat dari permasalahan yang disajikan oleh peneliti pada awal pembelajaran maupun selama proses pembelajaran berlangsung. Kebanyakan pendapat siswa muncul dari beberapa siswa yang monoton itu saja.

5) Berdasarkan hasil akhir tes hasil belajar pada siklus I, terungkap bahwa siswa belum mampu menyelesaikan permasalahan yang diberikan secara terstruktur, siswa masih asal-asalan dalam menjawab soal.

Berdasarkan temuan dari kegiatan observasi yang dilakukan selama pelaksanaan tindakan siklus I, maka diadakan upaya untuk memperbaiki proses tindakan pada siklus II, yaitu sebagai berikut.

1) Meningkatkan motivasi belajar siswa

2) Memberikan kesempatan lebih banyak pada siswa untuk bertanya dan mengajukan pendapat mengenai materi yang dibahas selama proses pembelajaran berlangsung.

3) Menunjuk siswa-siswa yang kurang aktif dalam berpendapat untuk mencoba mengajukan pendapatnya agar siswa tersebut menjadi lebih berani mengungkapkan pendapatnya.

4) Membimbing dan memantau siswa secara lebih intensif, agar kegiatan diskusi kelas tidak didominasi oleh siswa-siswa tertentu saja.
Proses pembelajaran pada siklus II berlangsung dalam 3 kali pertemuan, yang terdiri atas 2 kali pertemuan untuk kegiatan belajar mengajar, 1 kali pertemuan untuk tes akhir siklus. Pada pertemuan pertama, peneliti mengabsen siswa dan seluruh siswa hadir. Pada kegiatan inti dimulai dengan penyajian materi oleh peneliti. Kemudian siswa di minta bergabung ke dalam kelompok yang terdiri dari 4-5 orang yaitu kelompok yang sudah terbentuk sebelumnya.

Guru membagikan LKS kepada masing-masing kelompok dan meminta untuk mengerjakan LKS itu bersama-sama. Guru meminta anggota kelompok harus bekerja sama. Setelah masing-masing kelompok selesai mengerjakan LKS yang diberikan oleh guru, maka guru meminta hasil masing-masing kelompok untuk melakukan pemeriksaan hasil oleh kelompok yang lain. Kelompok yang tidak menjawab diminta untuk mendengarkan dan memberi tanggapan atas jawaban kelompok lainnya.

Setelah semua kelompok dapat menjawab dan memberi tanggapan maka tugas guru untuk melakukan konfirmasi dan penguatan atas kesalahan jawaban atau perbedaan pendapat yang mungkin terjadi pada saat diskusi. Di akhir pertemuan guru memberikan lembar kuesioner motivasi belajar, untuk mengetahui motivasi belajar siswa dalam mengikuti pembelajaran yang telah berlangsung.

Hasil belajar siswa pada siklus II diperoleh data sebagai berikut: sebanyak 35 orang siswa atau $92 \%$ dinyatakan tuntas, dan sisanya yaitu 3 orang siswa atau $8 \%$ dinyatakan belum memenuhi standar ketuntasan. Dengan demikian ketuntasan hasil belajar siswa pada siklus II sudah sesuai dengan kriteria yang ditentukan dan skor motivasi belajar siswa setelah implementasi model pembelajaran kooperatif tipe Student Team Achievemen Division adalah sebesar 2236 dan rataratanya sebesar 58.84 yang berkatagori positif.

Melalui perbaikan proses pembelajaran pada pelaksanakan siklus I, maka pelaksanakan proses pembelajaran pada siklus II telah nampak adanya 
peningkatan proses pembelajaran siswa. Adapun temuan-temuan yang diperoleh selama tindakan pelaksanakan siklus II, yaitu sebagai berikut.

1) Motivasi siswa dalam mengikuti pembelajaran meningkat bahkan ada yang berkatagori sangat positif.

2) Kondisi dan situasi belajar siswa pada setiap pertemuan menunjukkan situasi belajar yang lebih kondusif, jika dibandingkan dengan pertemuanpertemuan sebelumnya pada siklus I. Siswa sudah mulai terbiasa dengan implementasi model pembelajaran yang menuntut aktivitas tinggi seperti mau untuk mengajukan pendapat. Pada siklus II, tampak bahwa siswa sudah bisa memberikan penjelasan kepada temannya yang masih salah dengan menggunakan bahasa sendiri.

3) Dominasi siswa-siswa yang lebih mengerti sudah mulai berkurang. Siswasiswa tersebut sudah mau memberi kesempatan kepada rekan-rekannya untuk mengajukan pendapat, serta memberi penjelasan apabila rekannya tersebut mengalami kekeliruan, dengan bahasa sendiri.

4) Pada hasil tes akhir siklus II, terjadi peningkatan terhadap kualitas alasanalasan yang dibuat oleh siswa dari permasalahan yang diberikan.

Perbandingan motivasi dan hasil belajar pada siklus I dan siklus II disajikan dalam diagram berikut.

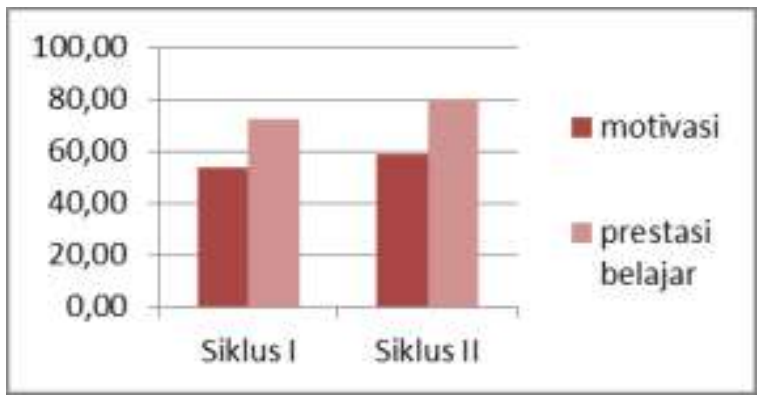

Gambar 2. Perbandingan Motivasi Belajar dan Hasil Belajar Siklus I dan Siklus II

\section{Pembahasan Hasil Penelitian}

Berdasarkan hasil penelitian yang telah dilaksanakan selama dua siklus menunjukkan adanya peningkatan motivasi belajar dan hasil belajar siswa melalui implementasi model pembelajaran kooperatif tipe Student Team Achievemen Division dalam pembelajaran tata hidang pada siswa kelas XI A3 SMK Negeri 2 Singaraja tahun pelajaran 2016/2017.

Hasil penelitian yang telah dilaksanakan selama 2 siklus adalah sebagai berikut. Hasil motivasi belajar pada siklus I ada 8 siswa memberikan respon cukup positif dan 30 siswa memberikan respon positif dengan rata-rata sebesar 53.5 yang berkatagori positif. Hasil belajar siklus I nilai rata-rata yang diperoleh adalah 72.63 dan standar deviasi 8.840, sebanyak 26 orang siswa atau $68 \%$ dinyatakan tuntas, dan sisanya yaitu 12 orang siswa atau $32 \%$ dinyatakan belum memenuhi standar ketuntasan. Dalam proses pelaksanaan siklus I masih belum optimal, hal ini disebabkan beberapa adanya beberapa permasalahan. Berdasarkan hasil refleksi siklus I, maka pelaksanaan tindakan pada siklus II mengacu pada perbaikan-perbaikan untuk meminimalisasi faktor penyebab belum optimalnya pembelajaran pada siklus I.

Berdasarkan perbaikan yang telah dilakukan, maka motivasi dan hasil belajar pada siklus II menunjukkan adanya peningkatan. Hasil motivasi belajar adalah sebagai berikut: 5 siswa memberikan respon cukup positif, 31 siswa memberikan respon positif dan 2 siswa memberikan respon sangat positif dan rata-rata motivasi belajar diperoleh sebesar 58.84 yang berkatagori positif. Untuk nilai rata-rata hasil belajar pada siklus II diperoleh sebesar 80.26 dan standar deviasi 7.552. Sebanyak 35 orang siswa atau $92 \%$ dinyatakan tuntas, dan sisanya yaitu 3 orang siswa atau $8 \%$ dinyatakan belum memenuhi standar ketuntasan. Berdasarkan hasil analisis data siklus I dan II dapat disebutkan bahwa terjadi peningkatan hasil belajar. Siswa menyatakan senang dan lebih tertantang untuk belajar tata hidang dengan menggunakan model kooperatif tipe Student Team Achievemen Division. Hal ini dikarenakan siswa menggunakan segenap kemampuan berpikirnya dan melatih siswa untuk berani tampil mengemukakan 
pertanyaan, menjawab, dan pendapat mereka.

Hasil penelitian ini memperkuat hasil penelitian yang relevan yang dilaksanakan oleh Putra (2013) yang menyatakan bahwa model pembelajaran kooperatif tipe STAD berpengaruh terhadap hasil belajar matematika siswa kelas V SD Gugus Ubud Tahun Ajaran 2012/2013. Hal tersebut terjadi karena model STAD dapat membantu dan memotivasi semangat untuk berhasil bersama.

Berdasarkan uraian hasil penelitian tersebut di atas dapat disampaikan bahwa implementasi model pembelajaran kooperatif tipe Student Team Achievemen Division dapat meningkatkan motivasi dan hasil belajar siswa kelas XI A3 SMK Negeri 2 Singaraja tahun pelajaran 2016/2017. Hal ini terjadi karena implementasi model pembelajaran kooperatif tipe Student Team Achievemen Division menyediakan suasana yang kondusif dalam pembelajaran. Siswa memiliki kesempatan untuk mengalami sendiri, berkreativitas untuk mengembangkan aspek-aspek berpikir mereka dalam pembelajaran.

\section{PENUTUP \\ Simpulan}

Berdasarkan hasil penelitian dan pembahasan dapat disimpulkan bahwa implementasi model pembelajaran kooperatif tipe Student Team Achievemen Division (STAD) dapat meningkatkan motivasi dan hasil belajar siswa kelas XI A3 SMK Negeri 2 Singaraja tahun pelajaran 2016/2017. Hal ini dapat dilihat dari nilai rata-rata motivasi belajar siklus I sebesar 52.5, di siklus II meningkat menjadi 58.84 yang berkatagori positif. Untuk rata-rata hasil belajar pada siklus I sebesar 72.63, dan pada siklus II meningkat menjadi 80.26.

\section{Saran}

Hal-hal yang disarankan kepada guru maupun peneliti lain dalam implementasi model pembelajaran kooperatif tipe Student Team Achievemen Division adalah 1) lebih mengoptimalkan kemampuan siswa dalam pembelajaran, 2) guru harus mengupayakan pembelajaran ke arah pembelajaran yang lebih menekankan kepada student center.
Setiap anak itu hebat, tugas guru adalah mengenali dan memfasilitasi anak tersebut.

\section{DAFTAR PUSKATA}

A.M, Sardiman. 2007. Interaksi dan Motuvasi Belajar Mengajar. Jakarta: RajaGravindo Persada

Arikunto, Suharsimi. 2002. Prosudur Penelitian Suatu Pendekatan Prektek. Jakarta: Bumi Aksara.

Arnyana, 2007. Stategi Belajar Mengajar. Singaraja: Universitas Pendidikan Ganesha.

Depdiknas, 2003. Pengembangan Kurikulum dan Sistem Penilaian Berbasis Kompetensi. Jakarta: Direktorat Jendral Pendidikan Dasar dan Menengah, Diretorat Pendidikan Lanjutan Pertama.

Indrawati, Ni Luh Gede Eka. 2017. "Penerapan Model Pembelajaran Kooperatif Tipe Student Team Achievement Divisions (Stad) Untuk Meningkatkan Hasil Belajar Matematika Siswa Kelas VI SD No. 1 Sading Kecamatan Mengwi Kabupaten Badung Semester I Tahun Pelajaran 2016/2017”. Journal of Education Action Research Vol 1, No 2 (2017): August 2017.

Jayano,Dw. Md. R. Dwi \& I Gst. Ngr. Japa I Md. Tegeh.2013.” Pengaruh Model Pembelajaran Kooperatif Tipe Stad Bermuatan Catur Pramana Terhadap Hasil Belajar Matematika Kelas V Sdn 1 Sangsit". MIMBAR PGSD Undiksha Vol 1, No 1 (2013).

Pujiono, Rudi.2017. "Penerapan Model
Pembelajaran Kooperatif Tipe
Student Team Achievement
Divisions (Stad) Untuk
Meningkatkan Motivasi Dan Hasil
Belajar Ipa Siswa Kelas V B Sdn
047 Tarakan". Journal of Education


Research and Evaluation Vol 1, No 4 (2017).

Putra. 2013. "Pengaruh Penerapan Model Pembelajaran Kooperatif Tipe STAD Terhadap Hasil Belajar Matematika Siswa Kelas V SD Gugus Ubud". Univesitas Pendidikan Ganesha, Volume 1.

Slavin, Robert E. (2008). Cooperative Learning. Teori, Riset, dan Praktik.Bandung: Nusa Media

Sudana, I Putu Ari \& I Gede Astra Wesnawa.2017." Penerapan Model Pembelajaran Kooperatif Tipe STAD Untuk Meningkatkan Hasil Belajar IPA". Jurnal Ilmiah Sekolah Dasar Vol 1, No 1 (2017): Februari 2017.

Wahyuni. 2014. "Pengaruh Penerapan Model Pembelajaran Kooperatif Tipe STAD Berbasis Interaksi Sosial Terhadap Hasil Belajar IPS Siswa Kelas V SD". Univesitas Pendidikan Ganesha, Volume 2 